\title{
ЗАХИСНІ ПОКРИТТЯ НА ОСНОВІ ХІТОЗАНУ ВІД ПАТОГЕННОЇ МІКРОФЛОРИ ХАРЧОВИХ ЯЄЦЬ
}

\author{
Чех Олександр Олександрович \\ аспірант \\ Сумський національний аграрний університет \\ ORCID: 0000-0002-8947-5269 \\ E-mail: olexa0701@gmail.com
}

Бордунова Ольга Георгіївна доктор сільськогосподарських наук, професор Сумський національний аграрний університет ORCID: 0000-0002-7120-1040 E-mail: bordunova.olga59@gmail.com

Проводились дослідження розробки композиції для обробки харчових яєць курей на основі хітозану у поєднанні з потужними дезінфектантами з групи органічних перекисних сполук надоцтовою кислотою (НОК) та перекисом водню, яка піддана електроактивуванню у водному розчині з використанням електродів з титану у комплексі заходів із захисту від патогенної мікросрлори, бактеріального і вірусного походження протягом усього терміну зберігання яєць шляхом нанесення на поверхню біоцидної і водночас екологічно безпечної нетоксичної захисної плівки. Встановлено вплив на шкаралупу яєць технічного кислоторозчинного хітозану, розчину надоцтової кислоти, які піддавали електролізу у реакторі, протягом 30 хв, за температури 60-70 C. Формували дві партії яєць - контроль та дослід. Дослідну групу обробляли шляхом нанесення на поверхню яєць біоцидної і екологічно безпечної нетоксичної захисної плівки. "Штучна кутикула», до складу якої входять речовина природного походження хітозан у поєднанні з потужними речовинами з групи органічних перекисних сполук надоцтовою кислотою (НОК) та перекисом водню, була піддана електроактивуванню у водному розчині з використанням електродів з титану. На 14, 19, 28 і 33 добу з поверхні шкаралупи харчових яєць робили змиви, які досліджували на БГКП, стафрілокок, сальмонели та спороутворюючі бактерії. Наведений склад композиції для обробки харчових яєць курей у комплексі заходів із захисту від патогенної мікрофрлори бактеріального і вірусного походження протягом усього терміну зберігання достовірно гальмує збільшення кількості патогенної мікрофрлори на поверхні харчових яєць. Рівень мікробної контамінації харчових яєць курей протягом зберігання зменшується. Так у контролі (харчові яйцях без обробки) на 14 добу з'являються бактерії групи кишкової палички (БГКП), - 15\%, на 19 добу 20\%, на 28 добу 40\% і на 33 добу 65 \%. Також кількість спороутворюючих бактерій, становить 10\% і стафрілококу 5\%. При обробці харчових яєць курей композицією на основі хітозану рівень контамінації менший: на 14 і 19 добу БГКП не виявлено, на 28 добу становить 5 \% і на 33 добу 10 \%, а спороутворюючі бактерії на рівні 5 \%. Хітозан в комплексі з іншими дезінсрікуючими речовинами дозволяє запобігти контамінації поверхні харчових яєць патогенною мікрофлорою протягом зберігання їх за підвищених рівнів температури і вологи.

Ключові слова: технологія, харчові яйця, робочий розчин, хітозан, композиція, патогенна мікрофрлора, біотехнологія.

DOI: https://doi.org/10.32845/bsnau.Ivst.2020.3.15

Курячі яйця входять до важливих дієтичних продуктів щоденного харчування, як джерела збалансованого, високоякісного з великим вмістом амінокислот білку, а також жирів, вітамінів, мінералів тощо. Але є й недоліки яєць сільськогосподарської птиці, як продукту харчування: це обмежені терміни умов зберігання і міцність, оскільки природні захисні оболонки яєць, шкаралупа та підшкаралупні оболонки, дуже чутливі до рівня температури, вологості, рівня контамінування бактеріальною мікрофрлорою $[3,11,18,22]$.

Відомо, що після відкладання куркою яйця починається процес погіршення його споживацьких властивостей через зменшення вмісту вологи та втрати вуглекислого газу $\left(\mathrm{CO}_{2}\right)$ [27]. Ці параметри впливають на якісні показники альбуміну та жовтка і можуть сприяти проникненню патогенних мікроорганізмів з поверхні шкаралупи всередину, що являє суттєвий ризик отруєння на сальмонельоз та інші небезпечні інфекційні захворювання [29].

Перед тим, як курячі яйця надходять до продажу, важливим етапом $€$ збирання, пакування, транспортування, зберігання. Під час цих операцій яєчна шкаралупа найчастіше частково або повністю пошкоджується, що спричинює значні економічні втрати для виробників та торгівельних установ $[3,4,11,26]$.

Для дезінфекції поверхні харчових яєць,використовують комплексні заходи для захисту від патогенної мікрофлори бактеріального і вірусного походження протягом тривалого зберігання шляхом нанесення на шкаралупу яєць захисної, біоцидної та водночас екологічно безпечної нетоксичної захисної плівки. Однією з найбільш перспективних речовин, яку можна використовувати в композиціях, що наносять у вигляді робочих розчинів на тверді поверхні $€$ хітозан, який можна використовувати для обробки харчових яєць курей у поєднанні з іншими хімічними речовинами [8].

Хітозан являє собою продукт деацетилювання хітину, який міститься в екзоскелеті ракоподібних і комах, клітинних стінках грибів і деяких водоростей. Дана речовина для обробки харчових яєць курей у комплексі з іншими препаратами із захисту від патогенної мікрофлори вірусного і бактеріального походження протягом усього терміну зберігання гальмує зростання кількості патогенної мікрофрлори на поверхні харчових яєць $[2,5,9]$. 
Одним із важливих методів підвищення терміну зберігання свіжих яєць є збереження їх при температурі 4-8 C, але в деяких регіонах і перепаду температури при транспортуванні це неможливо. Альтернативою для вирішення цієї проблеми є використання захисних покриттів, що наносяться на поверхню свіжознесених яєць, які можуть покращити механічні властивості природних захисних оболонок яєць і завдяки герметизації пор яєчної шкаралупи, зменшити проникність вологи, газів та мікроорганізмів $[10,14,15]$.

Аналізуючи сучасну зарубіжну і вітчизняну літературу і основуючись на власних дослідженнях встановлено, що біоцид на активність хітозану залежить від ступеня диацетилювання, тобто від частки аміносахаридних залишків з вільною аміногрупою. Збільшення ступеня диацетилювання хітозану веде до посилення антибактеріальних властивостей поліаміносахаріда, також від ступеня протонування вільних аміногруп полімеру, оскільки саме позитивно заряджені аміногрупи багато в чому визначають спорідненість хітозану до клітин мікроорганізмів. Зі збільшенням ступеня протонування аміногруп хітозану посилюються антибактеріальні властивості полімеру. Ступінь протонування полімеру залежить від кислотності середовища - чим більш кисле середовище, тим більш заряджений позитивно хітозановий полімер, тому при збільшенні кислотності середовища біоцидні властивості хітозану посилюються, а при залуженні - зменшуються [6,21].

Зазвичай зі збільшенням молекулярної маси хітозану його антибактеріальні властивості посилюються. Це пояснюється тим, що підвищується здатність взаємодіяти 3 клітинами мікроорганізмів при збільшенні молекулярної маси. Зазвичай така залежність спостерігається при оцінці антибактеріальних властивостей хітозану в кислих умовах - при низьких значеннях рН середовища (менше 6,5).

Однак, є відомості, що вказують про підвищення антибактеріальних властивостей хітозану при зменшенні його молекулярної маси, що пов'язують з кращою розчинністю більш низькомолекулярних форм полімеру. Зазвичай такі дані отримують при оцінці антибактеріальних властивостей хітозану в нейтральних або слабко лужних умовах - при середніх значеннях рН середовища (від 6,5 до 8,0).

Така розбіжність в залежності антибактеріальних властивостей хітозану від його молекулярної маси (ступеня полімеризації) зумовлює актуальність пошуку оптимальних по молекулярно-масовим параметрам зразків хітозану, які б мали досить високу антибактеріальну активність в широкому діапазоні кислотності середовища - як в кислих, так і в слабко лужних умовах, для подальшого його включення в антибактеріальну композицію $7,8,13]$.

Аналізуючі останні дослідження є таки способи застосування хітозану в композиції з іншими методами та дезінфіктантами для зниження бактеріального та вірусного обсіменіння.

Патентний пошук вказує на розроблені методики отримання вологоутримуючого композитного полімерного матеріалу на снові хітозану у $2 \%$ водному розчині оцтової кислоти [5]. Для попередження зараження харчових яєць курей пропонують обробку хітозаном (1\%) і гама-променями (2 kGy) [20]. Для подовження терміну зберігання яєць пропонується нанесення на поверхню шкаралупи суміші хітозану, гумінових кислот, гліцеролу, алкілполіглікозидів та води [23], або композиції на основі хітозану та соєвої олії [30]. Була досліджена екологічно безпечна композиція на основі карбоксі-метил-хітозану, гліцеролу та хлориду кальцію для захисту харчових яєць класу $\mathrm{A}$ [28]. $€$ відомості про розроблений спосіб попередження забруднення яєць патогенною мікрофлорою [12]. Створена композиція на основі хітозану композиція для підтримання показників якості яєць при зберіганні [19].

Інші досліди показували, що в технології електроактивування водних розчинів органічних та неорганічних сполук були підвищенні показники біологічної активності кінцевих продуктів щодо живих організмів, зокрема покращився рівень біоцидної активності щодо патогенної мікрофлори бактеріального, грибкового та вірусного походження [1]. Досліджені технології електрохімічної модифікації структури та модуляції хімічних/біологічних властивостей хітозану неорганічними сполуками, зокрема міддю з метою отримання біологічно активних композитів $[16,17,25]$ та технологія електрохімічної деструкції високомолекулярного хітозану у середовищі оцтової кислоти з використанням титан-рутенієвого (Ti/RuO2) аноду [24].

Усі наведені вище приклади досліджень пов'язані з використанням або хітозану з досить високою молекулярною масою, або з молекулярними масами в широкому діапазоні цього параметра і, таким чином, не враховують сильні відмінності в прояві антибактеріального впливу у зразках з різними молекулярно-масовими характеристиками. Це може призвести до недостатнього використання антимікробного потенціалу цього біополімеру. Так, зразки хітозану з більш високою молекулярною масою можуть значно втрачати свою активність в нейтральних і лужних умовах. Полідисперсні зразки хітозану, які містять молекули хітозану, що сильно розрізняються за молекулярної масою, також володіють недостатньою ефективністю щодо патогенної мікрофолори.

Матеріали та методи досліджень У зв'язку з цим метою досліджень є розробка композиції на основі хітозану у поєднанні з потужними дезінфектантами з групи органічних перекисних сполук надоцтовою кислотою (НОК) та перекисом водню для обробки харчових яєць курей у комплексі заходів із захисту від патогенної мікрофрлори бактеріального і вірусного походження протягом усього терміну зберігання яєць шляхом нанесення на поверхню біоцидної і водночас екологічно безпечної нетоксичної захисної плівки. При створенні препарату композиція була піддана електроактивуванню у водному розчині з використанням електродів з титану. Електроліз проводили протягом 30 хв за температури 60-70 C

Формували дві партії яєць - контроль та дослід. Курячі яйця ретельно відібрані за найкращою якістю і однаковою формою, без механічних пошкоджень, категорією та кольором шкаралупи. Дослідну групу обробляли шляхом нанесення на поверхню яєць біоцидної і екологічно безпечної нетоксичної захисної плівки «Штучна кутикула», до складу якої входять речовина природного походження хітозан у поєднанні з потужними речовинами з групи органічних перекисних сполук надоцтовою кислотою (НОК) та перекисом водню.

Композиція з хітозану була піддана електроактивуванню у водному розчині з використанням електродів з титану. Проводили мікробіологічні дослідження на рівень мікробної контамінації протягом зберігання яєць. Змиви з поверхні шкаралупи досліджували на бактерії групи кишкової палички (БГКП), стафілокок, сальмонели та спороутворюючі бактерії. Проводили спостереження протягом 33 днів. Досліди проводили у чотириразовій повторності $(n=4)$. 
Результати дослідження. Наведений склад композиції для обробки харчових яєць курей у комплексі заходів із захисту від патогенної мікрофрлори бактеріального і вірусного походження протягом усього терміну зберігання достовірно гальмує збільшення кількості патогенної мікрофлори на поверхні харчових яєць.

Дослідження біоцидної активності композиції «Штучна кутикула» для зменшення патогенної мікрофлори на поверхні харчових яєць курей проводили згідно ДСТУ 4769:2007 «Яйця курячі харчові. Технічні умови». Проби для хімічних і мікробіологічних аналізів відбирали згідно з ГОСТ 30364.0. 10.7 .
Досліджували такі мікробіологічні показники: кількість мезофільноаеробних та факультативно-анаеробних мікроорганізмів - згідно з ГОСТ 10444.15; бактерії групи кишкових паличок - згідно з ГОСТ 30518; патогенні мікроорганізми, в т.ч. роду Salmonella, коагулазопозитивні стафілококи. Вище згадані бактерії мають високу стійкість в зовнішньому середовищі, вони здатні не лише виживати, але і розмножуватися на продуктах харчування. На яєчній шкаралупі вони розмножуються з перших діб після знесення куркою яйця. За мікробіологічними показниками спостерігали зменшення кількості патогенної мікрофлори на шкаралупі протягом 33 діб (таб.1).

\begin{tabular}{|c|c|c|c|c|c|c|}
\hline \multicolumn{7}{|c|}{ Рівень мікробної контамінації харчових яєць курей протягом зберігання; (n=4) } \\
\hline $\begin{array}{c}\text { Методи обробки } \\
\text { харчових яєць }\end{array}$ & $\begin{array}{c}\text { Термін } \\
\text { відбору проб }\end{array}$ & $\begin{array}{c}\text { Кількість проб, } \\
\text { шт. }\end{array}$ & $\begin{array}{c}\text { БГКП } \\
(\%)\end{array}$ & $\begin{array}{c}\text { Стафілококи } \\
(\%)\end{array}$ & $\begin{array}{c}\text { Сальмонели } \\
(\%)\end{array}$ & $\begin{array}{c}\text { Спороутворюючі } \\
\text { бактерії } \\
(\%) \\
\end{array}$ \\
\hline \multirow{4}{*}{$\begin{array}{l}\text { Харчове яйце без } \\
\text { обробки (контроль) }\end{array}$} & Через 14 діб & 20 & 15 & - & - & - \\
\hline & Через 19 діб & 20 & 20 & - & - & - \\
\hline & Через 28 діб & 20 & 40 & - & - & - \\
\hline & Через 33 доби & 20 & 65 & 5 & - & 10 \\
\hline \multirow{4}{*}{$\begin{array}{l}\text { Композиція для } \\
\text { обробки харчових } \\
\text { яєць курей (дослід) }\end{array}$} & Через 14 діб & 20 & - & - & - & - \\
\hline & Через 19 діб & 20 & - & - & - & - \\
\hline & Через 28 діб & 20 & 5 & - & - & - \\
\hline & Через 33 доби & 20 & 10 & - & - & 5 \\
\hline
\end{tabular}

Наведений склад композиції для обробки харчових яєць курей у комплексі заходів із захисту від патогенної мікрофрлори бактеріального і вірусного походження протягом усього терміну зберігання достовірно гальмує збільшення кількості патогенної мікрофлори на поверхні харчових яєць. Рівень мікробної контамінації харчових яєць курей протягом зберігання зменшується. Так у контролі (харчові яйцях без обробки) на 14 добу з'являються бактерії групи кишкової палички (БГКП) - 15\%, на 19 добу 20\%, на 28 добу 40\% і на 33 добу $65 \%$. Також кількість спороутворюючих бактерій, становить 10\% і стафілококу 5\%. При обробці харчових яєць курей композицією на основі хітозану рівень контамінації менший: на 14 і 19 добу БГКП не виявлено, на 28 добу становить $5 \%$ і на 33добу $10 \%$, а спороутворюючі бактерії на рівні $5 \%$.

Висновки. Хітозан в комплексі з іншими дезінфікуючими речовинами дозволяє запобігти контамінації поверхні харчових яєць патогенною мікрофлорою протягом зберігання їх за підвищених рівнів температури і вологи, робочий розчин забезпечує зменшення кількості БГКП, стафілококу та спороутворюючих бактерій протягом тривалого терміну зберігання.

Подяки. Робота виконана за фінансової підтримки Мiністерства освіти і науки України (номер державної реєстрації 0119U100551)

\section{Список використаної літератури:}

1. Бахир В. М. Электрохимическая активация: изобретения, техника, технология. ВИВА-СТАР, 2014. С. 36.

2. Бордунова О. Г., Денисов Р. В., Самохіна $Є$. А., Самохина Е. А. Вивчення впливу передінкубаційної технології «штучна кутикула» на розвиток ембріонів та збереженість молодняка курей. Вісник Сумського національного аграрного університету. Науковий журнал. Сер. «Тваринниитво». Сумський національний аграрний університет. Суми : СНАУ, 2015. Вип. 6 (28). C. 102-107.

3. Вечеря Ю. О. Вплив різних чинників на виводимість яєць сільськогосподарської птиці. Сучасне птахівництво 2015. Bun. 7-8. C. 22-24. 103-108.

4. Заболотний В. С. Сучасні тенденції виробництва яєць в Україні. Економіка та управління АПК. 2014. № 1. С.

5. Кузнецов В. А. Способ получения влагопоглощающего композиционного полімерного материала. RU 30.01.2018 C08L 5/08 2016110178 (RU).

6. Куликов С. Н., Тюрин Ю. А., Долбин Д. А., Хайруллин Р. З. Роль структуры в биологической активности хитозана. Вестник Казанского технологического университета. 2007. № 6. С. 10-15.

7. Куликов С. Н., Чирков С. Н., Ильина А. В., Лопатин С. А, Варламов В. П. Влияние молекулярной массы хитозана на его противовирусную активность в растениях. Прикладная биохимия и микробиология. 2006. Т. 42. № 2. С. 224-228.

8. Подшивалов А. В., Захарова М. В., Успенская М. В., Самуйлова Е. О. Состав биодеградируемой полимерной композиции для обработки пищевых продуктов (19) RU (11) 2649 981(13) С1 РФ (51) МПК А23В 4/10 (2006.01) Заявка: 2017120355, 09.06.2017 Опубликовано: 06.04.2018 Бюл. № 10.

9. Якубчак О. М. Чим краще обробити? Порівняльна оцінка сучасних і традиційних дезінфекційних засобів, що використовуються в галузі птахівництва. Сучасне птахівництво. 2006. № 6. С. 14-15.

10. Attila E. Pavlath W. Orts (auth.), Kerry C. H., Milda E. E. (eds.) Edible films and coatings for food applications. SpringerVerlag New York.2009. pp. 416. 
11. Donald D. Bell, William D. Weaver Jr. (eds.) commercial chicken meat and egg production. Springer US. 2002. pp.1365.

12. Bhale S., No H. K., Prinyawiwatkul W., Farr A. J., Nadarajah K., Meyers S. P. Chitosan coating improves shelf life of eggs. Journal of food science. 2003. Issue 68 (7). pp. 2378-2383.

13. Chung Y. C., Kuo C. L., Chen C. C. Preparation and important functional properties of water-soluble chitosan produced through maillard reaction. Bioresource Technol. 2005. Issue.96. (13). pp. 1473-1482.

14. Elizabeth A. B., Robert D. H., Jinhe B. Edible coatings and films to improve food quality. CRC Press. 2011. pp. 450.

15. Elizabeth A B., Robert D H., Jinhe B. Edible coatings and films to improve food quality. CRC Press. 2012. pp. 448.

16. Elmezayyen A. S. and Reicha F. M. Preparation of Chitosan Copper Complexes: Molecular dynamic studies of chitosan and chitosan copper complexes. Open Journal of Applied Sciences. 2015. Issue 5. pp. 415-427.

17. Gary H. Method of electrochemical formation of noble nanoparticles in a chitosan matrix W02011106526A2 2011-02-24.

18. Hester P. Y. Egg innovations and strategies for improvements. Academic Press, 2017. pp. 646.

19. Kim S. H., Youn D. K., No H. K., Choi S. W., Prinyawiwatkul W. Effects of chitosan coating and storage position on quality and shelf life of eggs International journal of food science \& technology. 2009. Issue 44 (7). pp. 1351-1359.

20. Kim B. R., Jo J. R., Hwang I. A. Egg's shelf life extention used chitosan coating and gamma irradiation KR20170127823 (A) - A23B5/015; A23B5/06 KR20160058519 20160513 KR20160058519 20160513.

21. Maria P., Montero Garcia, M. Carmen G., M. Elvira L., Gustavo V. Edible films and coatings: fundamentals and applications.CRC Press, Taylor \& Francis Group. 2017. pp. 598.

22. Maureen B., Yves N., Filip V.Immerseel food science, technology and nutrition improving the safety and quality of eggs and egg products: Volume 2: Egg safety and nutritional quality. Woodhead Publishing. 2011. pp. 448.

23. NiuYuhua, HaoMingde, Yan Xiaogu, Wang Chen, Song Jie Egg-preserving humic acid film and preparation method and using method thereof CN106962457 (A) A23B5/06 CN20171298997 20170427.

24. Quanyuan C., Zhiming G., Tingming F., Yan L., Hongchang S., Fengsheng L. Kinetic study of chitosan degradation by an electrochemical process . Polymer Bulletin August 2011. Volume 67, Issue 4. pp. 571-582.

25. Reicha F., Shebl A., Badria F. and EL-Asmy, A. Electrochemical synthesis, characterization and biological activity of chitosan metal complexes. International Journal of Basic and Applied Chemical Sciences, 2012. Issue 2. pp. 7-22.

26. Solomon S. E., Bain M. M., Cranstoun S., Nascimento V. (auth.), Microbiology of the avian Egg .Springer US. 1994.

27. Samokhina Y. A., Bordunova O. G., Loboda V. B., Chernenko O. M., Dolbanosova R. V., Chivanov V. D. Study of the correlations between the dynamics of thermal destruction and the morphological parameters of biogenic calcites by the method of thermoprogrammed desorption mass spectrometry (TPD-MS). Springer Proceedings in Physics, Issue 240. Springer, Singapore, 2020. pp. 37-50.

28. Sun J., Xu B. Carboxymethyl chitosan co-mixed fresh-keeping agent and film-coating fresh-keeping method for fresh egg CN103749647 (A) A23B5/06 CN20131493467 20131018.

29. Yoshinori M. Egg Bioscience and Biotechnology. Wiley-Interscience. 2007. pp. 378.

30. Wardy W., Torrico D. D., Herrera J. A. Soybean oil-chitosan emulsion affects internal quality and shelf-life of eggs stored at 25 and 4 C. International Journal of Food Science \& Technology. 2013. Issue 48 (6).pp. 1148-1156.

\section{References:}

1. Bakhyr, V. M. 2014. Elektrokhymycheskaia aktyvatsyia: yzobretenyia, tekhnyka, tekhnolohyia [Electrochemical activation: inventions, techniques, technology]. VYVA-STAR, pp. 36.

2. Bordunova, O. H., Denysov, R. V., Samokhina, Ye. A. and Samokhyna, E. A. 2015. Vyvchennia vplyvu peredinkubatsiinoi tekhnolohii «shtuchna kutykula» na rozvytok embrioniv ta zberezhenist molodniaka kurei [Study of the influence of pre-incubation technology "artificial cuticle" on the development of embryos and the safety of young chickens]. Visnyk Sumskoho natsionalnoho ahrarnoho universytetu: naukovyi zhurnal. Ser. «Tvarynnytstvo» Sumskyi natsionalnyi ahrarnyi universytet. Sumy. SNAU, issue 6 (28), pp. 102-107.

3. Vecheria, Yu. O. 2015. Vplyv riznykh chynnykiv na vyvodymist yaiets silskohospodarskoi ptytsi. [Influence of various factors on hatchability of poultry eggs]. Suchasne ptakhivnytstvo, issue 7-8, pp. 22-24.

4. Zabolotnyi, V. S. 2014. Suchasni tendentsii vyrobnytstva yaiets v Ukraini [Current trends in egg production in Ukraine]. Ekonomika ta upravlinnia APK, issue 1, pp. 103-108.

5. Kuznetsov, V. A. Sposob poluchenyia vlahopohloshchaiushcheho kompozytsyonnoho polymernoho materyala [Method of obtaining a moisture-absorbing composite polymeric material]. RU 30.01.2018 C08L 5/08 2016110178 (RU).

6. Kulykov, S. N., Tiuryn, Yu. A., Dolbyn, D. A. and Khairullyn, R. Z., 2007. Rol strukturi v byolohycheskoi aktyvnosty khytozana [The role of structure in the biological activity of chitosan]. Vestnyk Kazanskoho tekhnolohycheskoho unyversyteta, issue 6, pp. 10-15.

7. Kulykov, S. N., Chyrkov, S. N., Ylyna, A. V., Lopatyn, S. A. and Varlamov, V. P., 2015. Vlyianye molekuliarnoi massi khytozana na eho protyvovyrusnuiu aktyvnost $\mathrm{v}$ rastenyiakh [Effect of the molecular weight of chitosan on its antiviral activity in plants]. Prykladnaia byokhymyia y mykrobyolohyia, issue 42, № 2, pp. 224-228.

8. Podshyvalov, A. V., Zakharova, M. V., Uspenskaia, M. V., and Samuilova, E. O. Sostav byodehradyruemoi polymernoi kompozytsyy dlia obrabotky pyshchevikh produktov [Composition of a biodegradable polymer composition for food processing] (19) RU (11) 2649 981(13) C1 RF (51) MPK A23B 4/10 (2006.01) Zaiavka: 2017120355, 09.06.2017 Opublykovano: 06.04.2018 Biul. № 10. 
9. lakubchak, O. M., 2006. Chym krashche obrobyty? Porivnialna otsinka suchasnykh i tradytsiinykh dezinfektsiinykh zasobiv, shcho vykorystovuiutsia v haluzi ptakhivnytstva [What is more beautiful to grind? Ratio assessment of the occasional and traditional disinfectious diseases, how to get sick in the branch poultry]. Suchasne ptakhivnytstvo, issue 6, pp. 14-15.

10. Attila, E. Pavlath, W., Kerry, C. H., and Milda, E. E., 2009. Edible Films and Coatings for Food Applications. SpringerVerlag New York. pp. 416.

11. Donald, D. Bell and William, D. Weaver Jr., 2002. Commercial chicken meat and egg production. Springer US. pp.1365.

12. Bhale, S., No H. K., Prinyawiwatkul, W., Farr, A. J., Nadarajah, K. and Meyers, S. P., 2003. Chitosan coating improves shelf life of eggs. Journal of food science, issue 68 (7). pp. 2378-2383

13. Chung, Y. C., Kuo, C. L. and Chen, C. C., 2005. Preparation and important functional properties of water-soluble chitosan produced through maillard reaction. Bioresource Technol, issue 96, (13), pp. 1473-1482.

14. Elizabeth, A. B., Robert, D. H. and Jinhe, B. C., 2011. Edible coatings and films to improve food quality. CRC Press. pp. 450.

15. Elizabeth, A B., Robert, D H., and Jinhe, B.C. 2012. Edible coatings and films to improve food quality. CRC Press. pp. 448.

16. Elmezayyen, A. S. and Reicha, F. M., 2015. Preparation of chitosan copper complexes: molecular dynamic studies of chitosan and chitosan copper complexes. Open Journal of Applied Sciences, issue 5, pp. 415-427.

17. Gary, H. Method of electrochemical formation of noble nanoparticles in a chitosan matrix WO2011106526A2 2011-02-24.

18. Hester, P. Y., 2017. Egg innovations and strategies for improvements. Academic Press. pp. 646.

19. Kim, S. H., Youn, D. K., No, H. K., Choi, S. W. and Prinyawiwatkul W. H., 2009. Effects of chitosan coating and storage position on quality and shelf life of eggs. International journal of food science \& technology, issue 44 (7), pp. 1351-1359.

20. Kim, B. R., Jo, J. R., Hwang, I. A. Egg's shelf life extention used chitosan coating and Gamma irradiation KR20170127823 (A) - A23B5/015; A23B5/06 KR20160058519 20160513 KR20160058519 20160513.

21. Maria, P., Garcia, M. M., Carmen, G. M. Elvira, L. and Gustavo V., 2017. Edible films and coatings: fundamentals and applications.CRC Press, Taylor \& Francis Group. pp. 598.

22. Maureen, B., Yves, N., and Filip, V., 2011. Immerseel food science, technology and nutrition improving the safety and quality of eggs and egg products: Volume 2. Egg safety and nutritional quality. Woodhead Publishing. pp.448.

23. NiuYuhua, H., Yan X., Wang C. and Song, J. Egg-preserving humic acid film and preparation method and using method thereof CN106962457 (A) A23B5/06 CN20171298997 20170427.

24. Quanyuan, C., Zhiming, G., Tingming, F., Yan, L., Hongchang, S. and Fengsheng L., 2011. Kinetic study of chitosan degradation by an electrochemical process. Polymer Bulletin August, Volume 67, issue 4, pp. 571-582.

25. Reicha, F., Shebl, A., Badria, F. and EL-Asmy, A., 2012. Electrochemical Synthesis, Characterization and Biological Activity of Chitosan Metal Complexes. International Journal of Basic and Applied Chemical Sciences, issue 2, pp. 7-22.

26. Solomon S. E., Bain M. M., Cranstoun S. and Nascimento V., 1994. Microbiology of the avian Egg. Springer US.

27. Samokhina, Y. A., Bordunova, O. G., Loboda, V. B., Chernenko, O. M., Dolbanosova, R. V. and Chivanov, V. D., 2020. Study of the correlations between the dynamics of thermal destruction and the morphological parameters of biogenic calcites by the method of thermoprogrammed desorption mass spectrometry (TPD-MS). Springer Proceedings in Physics, Springer, Singapore, issue 240, pp. 37-50.

28. Sun, J., and $\mathrm{Xu}, \mathrm{B}$. Carboxymethyl chitosan co-mixed fresh-keeping agent and film-coating fresh-keeping method for fresh egg CN103749647 (A) A23B5/06 CN20131493467 20131018.

29. Yoshinori, M., 2007. Egg Bioscience and Biotechnology. Wiley-Interscience. pp. 378.

30. Wardy, W., Torrico, D. D. and Herrera, J. A., 2013. Soybean oil-chitosan emulsion affects internal quality and shelf-life of eggs stored at 25 and 4 C. International Journal of Food Science \& Technology, issue 48 (6), pp. 1148-1156.

Czech Alexander Alexandrovich, postgraduate

Bordunova Olga Georgievna, Doctor of Agricultural Sciences, Professor

Sumy National Agrarian University (Sumy, Ukraine)

Protective coatings based on chitosane from the pathogenic microflora of food eggs

Studies of the development of a composition based on chitosan in combination with powerful disinfectants from the group of organic peroxides with peracetic acid (PA) and hydrogen peroxide, which is subjected to electroactivation in aqueous solution using titanium electrodes for processing chicken eggs in a complex of microprotective, bacterial and viral origin throughout the shelf life of eggs by applying to the surface of biocidal and at the same time environmentally friendly non-toxic protective film. The effect of technical acid-soluble solution of peracetic acid, which was subjected to electrolysis in the reactor, for $30 \mathrm{~min}$, at a temperature of 60-700 $\mathrm{C}$. Formed two batches of eggs - control and experiment. The experimental group was treated by applying a biocidal and environmentally friendly non-toxic protective film to the surface of the eggs. The "artificial cuticle", which contains a substance of natural origin chitosan in combination with powerful substances from the group of organic peroxides with peracetic acid (PA) and hydrogen peroxide, was subjected to electroactivation in aqueous solution using titanium electrodes. On days 14, 19, 28, and 33, washings were made from the surface of the eggshell, which were examined for bacteria of the Escherichia coli, staphylococcus, salmonella, and spore-forming bacteria. The composition of the composition for processing edible eggs of chickens in a set of measures to protect against pathogenic microflora of bacterial and viral origin throughout the shelf life significantly inhibits the increase in the number of pathogenic microflora on the surface of edible eggs. The level of microbial contamination of chicken eggs during storage decreases. Thus, in the control (food eggs without processing) on the 14th day there are bacteria of the Escherichia coli group - 15\%, on the 19th day 20\%, on the 28 th day $40 \%$ and on the $33 \mathrm{rd}$ day $65 \%$. Also, the number of spore-forming bacteria is $10 \%$ and staphylococcus $5 \%$. When processing

Вісник Сумського національного аграрного університету 
edible eggs of chickens with a composition based on chitosan, the level of contamination is lower: on the 14th and 19th day bacteria of the Escherichia coli groupwas not detected, on the 28th day it is 5\% and on the 33rd day $10 \%$, and spore-forming bacteria at the level of $5 \%$. Chitosan in combination with other disinfectants can prevent contamination of the surface of food eggs with pathogenic microflora during storage at elevated levels of temperature and humidity.

Key words: technology, food eggs, working solution, chitosan, composition, pathogenic microflora, biotechnology.

Дата надходження до редакції: 25. 10.2020 р. 